7. Petrenko O.B. Do problemy klasyfikatsii dzherelnoi bazy istoryko-pedahohichnoho doslidzhennia. Pedahohichnyi dyskurs [To the problem of classification of the source base of historical and pedagogical research]. Pedagogical discourse. 2013. Vyp. 15. S. 536-541.

8. Raskyn D.Y. Klassyfykatsyia ystoryko-pedahohycheskykh ystochnykov [Classification of historical and pedagogical sources]. Historiographical and methodological problems of studying the history of the native school and pedagogy. M., 1989. S. $85-98$.

9. Strazhnikova I. Rozvytok pedahohichnoi nauky v doslidzhenniakh Zakhidnoho rehionu Ukrainy druhoi polovyny KhKh - pochatku KhKhI stolittia: istoriohrafichnyi kontekst [The development of pedagogical science in the researches of the Western region of Ukraine in the second half of the 20th the beginning of the 21st century: the historiographical context]. Ivano-Frankivsk: NAIR, 2015. $616 \mathrm{~s}$.

10. Sukhomlynska O.V. Istoryko-pedahohichnyi protses: novi pidkhody do zahalnykh problem [Historical and pedagogical process: new approaches to common problems]. K., 2003. $68 \mathrm{~s}$.

Одержано статтю: 7.02.2019

Прийнято до друку: 21.03.2019

УДК $37.015 .31: 27-42$

DOI: $10.15330 /$ esu. $15.51-59$

\section{Наталія Салига,}

кандидат педагогічних наук, доцент, ДВНЗ “Прикарпатський національний університет імені Василя Стефаника" (м. Івано-Франківськ, Україна)

Nataliia Salyha, Candidate of pedagogical scienses $(\mathrm{PhD})$, Assosiate Proffesor, Vasyl Stefanyc Precarpathian National University (Ivano-Frankivsk, Ukraine) natalii58@ukr.net

\title{
ПОГЛЯДИ ІОАННА ПАВЛА І НА ПРОБЛЕМИ ВИХОВАННЯ ДІТЕЙ ТА МОЛОДІ НА ЗАСАДАХ ХРИСТИЯНСЬКОЇ МОРАЛІ
}

\section{VIEWS OF JOHN PAUL II ON THE PROBLEMS OF CHILD AND YOUTH EDUCATION FROM THE STANDPOINT OF CHRISTIAN MORALITY}

Стаття присвячена проблемі виховання дітей та молоді з позиџій християнської моралі у творчості та просвітницькій діяльності Папи Римського Іоанна Павла II, який був не лиие видатною духовною особою, дипломатом, психологом, філософом, істориком, а й справжнім педагогом світу, одним із найбільи харизматичних діячів ХХ cm. У статті розглянуто філософсько-педагогічні прачі вченого, проаналізовано гуманістичну сутність $i$ зміст його ідей, розкрито загальнолюдське значення його духовної спадчини в реалізації ідей християнськой моралі сучасної молоді.

Ключові слова: мораль, християнська мораль, виховання, Іоанн Павло II.

The article focuses on the problem of educating children and young people from the standpoint of Christian morality in the works and educational activities of Pope John Paul II who was not only a prominent clergyman, diplomat, psychologist, philosopher, historian, but a true teacher of the world, one of the most charismatic leaders of the 20th century. It deals with the philosophical and pedagogical works of the scientist, analyzes the humanistic core and content of his ideas, reveals the universal significance of his spiritual heritage in implementing the ideas of Christian morals of modern youth.

John Paul II left behind a wealth of scientific achievements. Most members of the Ukrainian scientific community know him only as the Pope, the leader of the Catholic Church. However, it would be a big mistake to limit this figure to religious activity only. Among the rich creative heritage of the Pontiff, there are works that have a direct bearing on pedagogy. The views of John Paul II on the education of children and young people from the standpoint of Christian morality are reflected in voluminous pastoral teachings, apostolic messages, 
philosophical articles on moral and ethical issues. All his works point to the need to educate children and youth in the Christian spirit.

John Paul II drew attention of scientists of various fields of knowledge to the problems of education: philosophers, psychologists, physiologists, linguists, teachers, doctors. The Pontiff believed that the purpose of education is, above all, the upbringing of a person in a man. On the deep conviction of John Paul II, the basic principles of humanistic pedagogy, which forms the high spirituality of the individual, are laid in the Christian religion specifically.

The Pontiff highlighted the importance of national education. As a highly spiritual person, he especially emphasized the right of every nation to its language and culture. He considered Christian education to be the basis of the moral formation of a growing generation, since it covers all spheres of human life: personal, family, civil, national, social, etc. Christian canons are the basis for the spread of common spiritual values, such as kindness, decency, love, loyalty, honesty, dignity, wisdom, justice, etc., among children and young people.

Key words: morality, Christian morality, education, John Paul II.

Актуальність постановки проблеми. Проблема духовно-морального виховання дітей та молоді в усі історичні періоди була однією 3 найактуальніших. А сьогодні, в період складних політичних і соціально-економічних перетворень, які охопили наше суспільство, вона набуває особливого значення. Незважаючи на те, що людина живе у матеріальному світі і має потреби матеріальні, духовні ідеали завжди вважалися найвищими цінностями.

Останнім часом змінюється людське суспільство, знецінюється престиж інтелектуальної діяльності, спостерігається заниження моральних критеріїв своєї та чужої поведінки, суттєво погіршуються моральні взаємини між людьми, зростає культ грошей, сили та влади. На жаль, сьогодні ми часто спостерігаємо, шо ці риси все частіше проявляються у поведінці не лише підлітків, але навіть і дітей. Не випадково в Державній національній програмі "Освіта" ("Україна XXI століття") виховання духовності та моральності визначається як одне 3 головних завдань розбудови демократичного суспільства.

Зазначені проблеми дають можливість зробити висновок, що поряд iз визначеними державою напрямками i формами виховання підростаючого покоління важливим постає питання відродження християнської моралі у суспільстві і збільшення ролі громадських організацій, церкви, які можуть доповнити або частково взяти на себе виконання певних виховних функцій. У цьому контексті важливого значення набуває багата педагогічна спадщина Святого Отця Іоанна Павла II.

Аналіз останніх досліджень i публікацій, у яких започатковано розв'язання проблеми.

Наукова спадшина Іоанна Павла II досліджується, перш за все, у філософсько-просвітницьких колах Західної Європи. Зокрема, публікації Я.Грондельського, П.Джуєтті та ін., присвячені бібліографії праць Іоанна Павла II, перекладених європейськими мовами. Окремі аспекти багатогранної спадщини мислителя досліджували К.Вронська, Я.Дашиковська, Вайгель Джорджа, П.Казьмерчак, А.Макувка, С.Хробак, ін.

Однак в українському науковому середовищі Іоанн Павло II залишається постаттю маловідомою (якщо не брати до уваги релігійне середовище), хоча український читач завдяки католицьким виданням має доступ майже до всіх творів Папи Римського. Серед сучасних дослідників наукового доробку Іоанна Павла II заслуговують на увагу дослідження І.Захари, О.Михайліва, Н.Ничкало, М.Сахній, 
О.Федоріва, в яких розглядаються основні етапи громадської, церковної, просвітницької та наукової діяльності Понтифіка.

Аналіз робіт як зарубіжних, так і українських вчених містить чимало цінної інформації із зазначеної проблеми і свідчить про те, що вивчення науковофілософської спадщини польського мислителя тільки розпочато. Недостатнє дослідження із зазначеної теми дало поштовх до поглибленого аналізу педагогічної спадщини Іоанна Павла II, так як наявні наукові напрацювання вчених у переважній більшості відображають лише іiі окремі складові. Багатогранна спадщина Святого Отця на сьогоднішній день не поцінована належним чином, хоча містить у собі велику кількість дуже цінних і актуальних педагогічних ідей. У статті розкрито філософсько-педагогічні погляди Іоанна Павла II на проблеми виховання сучасної молоді з позицій християнської моралі.

Мета і завдання дослідження. Мета статті - проаналізувати педагогічні погляди та просвітницьку діяльність Іоанна Павла II та обгрунтовути важливість його творчого доробку для виховання у дітей та молоді християнських чеснот.

Виклад основного матеріалу. Мислителем світового рівня, постаттю, одухотвореною подвигом Христа, є Іоанн Павло II (1920-2002). Американський богослов Вайгель Джордж присвятив Папі Римському свою книгу “Свідок надії, в якій написав: “Він став найпомітнішою людиною, яка будь-коли жила на Землі: нема сумніву, що його бачили наочно більше людей, ніж будь-кого іншого. А коли взяти до уваги ще й телебачення 3 його незмінною глядацькою аудиторією, то важко собі уявити, який величезний засяг мало Папине спілкування 3 людством, у скільки світів-культур він проник" [1, с. 4].

Іоанн Павло II залишив після себе багатий науковий доробок. Більшість українського наукового середовища знають його лише як Папу Римського - Главу Католицької церкви. Однак було б великою помилкою обмежувати цю постать лише релігійною діяльністю, так як “за сімсот двадцять днів паломництва за межами Риму Святий Отець проголосив три тисячі сімдесят вісім звернень i проповідей. У самому Римі здійснив понад сімсот пастирських візитів: до в'язниць, університетів, релігійних інститутів, монастирів, семінарій, шпиталів тощо" [11].

Народився Кароль Войтила 18 травня 1920 року у Вадовицях, що поблизу Кракова, у родині військового. Батько був глибоко віруючою людиною і став прикладом для майбутнього Понтифіка. “Дивлячись на нього, - пригадував Іоанн Павло II, я навчився, що треба до самого себе ставити вимоги і домагатися виконання власних обов'язків" [11, с. 5]. У ранньому віці Кароль втратив маму, пам'яті якій він значно пізніше присвятить поему “Давид - ренесансний псалтир”.

Закінчивши Вадовицьку гімназію, Кароль студіював польську філологію в Ягеллонському університеті, після чого прийняв рішення вступити на духовну стежину і стати священиком. Навчався в Краківській духовній семінарії та аспірантурі Римського університету. У Римі отримав докторат (1948), а захищався в Ягеллонському університеті (3 етики) у 1953 році. Викладав етику на філософському факультеті Люблінського католицького університету, де в 1956 році очолив кафедру етики в цьому ж університеті. Водночас працював у Кракові вікарним священником, душпастирем студентської молоді і душпастирем служби здоров'я.

Кароль Войтила дебютував на початку 60-х років минулого століття філософсько-етичними творами “Любов і відповідальність"(Люблін, 1960) та “Особа і чин” (Краків, 1969), що засвідчили про появу самобутнього філософа, 
який зробив вдалу спробу розкрити все багатство християнського персоналізму. Під псевдонімами Андрій Явень та Станіслав Андрій Груда він публікував свої поезії та драми.

16 жовтня 1978 року в житті Кароля Войтили наступає особливий період, який символічно можна назвати пастирсько-релігійним. Він розпочався від дня обрання його Папою Римським та прийняттям імені Іоанна Павла II. Титул - Папа (від грецьк. - батько), який, починаючи із VII століття, присуджували виключно римському єпископу [11, с. 7].

Серед багатої творчої спадщини Понтифіка $\epsilon$ праці, які мають безпосереднє відношення до педагогіки. До них, в першу чергу, належать папські енцикліки (офіційне навчання Глави Католицької Церкви), серед яких особливо цікавою є енцикліка Veritatis splendor (1993), присвячена основним принципам християнської моралі.

Погляди Іоанна Павла II на проблеми виховання дітей та молоді 3 позицій християнської моралі знайшли своє висвітлення і обгрунтування також у 15 об'ємних пастирських повчаннях (адхортаціях) та 42 апостольських посланнях. Перу Понтифіка належить більше як 200 філософських статей етичної та персоналістичної проблематики, об’єднаних у збірники “Люблінські лекції, “Збірник етичних елементів” тощо. Загалом науково-філософський доробок Іоанна Павла II налічує 58 томів. Всі його твори вказують на необхідність виховання дітей та молоді у християнському дусі.

До конщепту “дитина" Іоанн Павло II привертав увагу вчених різних галузей знань: філософів, психологів, фізіологів, лінгвістів, педагогів, дефектологів, лікарів. Святий Отець називав дітей “даром життя", “даром Бога", “посмішкою неба, подарованою землі”, “справжніми коштовностями сім’ї і суспільства”, “надією, яка постійно розцвітає наново, майбутнім, яке завжди залишається відкритим" [11, с. 6].

У всіх своїх творах, як філософських, так і педагогічних, Святий Отець дотримується християнського персоналістичного напрямку. Персоналізм

(від лат. persona - особа, особистість) - це філософська течія християнського спрямування, яка зародилася на початку XX століття. В їі основі лежить вчення про те, що світ $\epsilon$ сукупністю духовних особистостей, якими керує "вища верховна особа - Бог”, зв'язок із яким є необхідним елементом розвитку особистості Людини [18, с. 16].

Посилаючись на Біблію, Іоанн Павло II наголошував на тому, що саме виховання має "провадити вихованця до євангельської постаті Ісуса Христа як джерела всякої правди, зразка та ідеалу” [18, с. 127]. Понтифік вважав, що метою виховання $\epsilon$, перш за все, виховання людини в людині: “Виховання служить “очоловіченню” людини. А людина, будучи нею від першої хвилини свого зачаття в лоні матері, поступово вчиться бути людиною. І цей процес ототожнюється саме із вихованням" [14, с. 54].

“Формування людськості" є для Івана Павла II синтезом педагогічної мети, яку він розглядав у потрійній площині: особистої, суспільної та релігійної зрілості вихованця. Щодо першої, то виховання повинно вести до формування вільних $\mathrm{i}$ свідомо відповідальних громадян. Саме це є характерною рисою персоналістичної педагогіки Івана Павла II та означає готувати особистість до дорослого життя, допомогти їй “відкрити себе в аспекті інших осіб" [14]. Не випадково один із фільмів про Понтифіка має назву “Кароль, Папа який залишився людиною". 
Особливу увагу Іоанн Павло II приділяв суспільній зрілості особистості. У праці "Віра і розум" (1998) він стверджував: “Людина не знайде істинних цінностей, якщо замкнеться в собі. Кожен покликаний пройти свій власний життєвий шлях завжди “у відношенню з іншими та для інших. Цю обов'язкову умову має виконати кожен, щоб стати самим собою і розвиватися як доросла і зріла особистість” [5, нр.25].

Іван Павло II, будучи в першу чергу релігійним мислителем, не міг оминути ще одного виховного середовища - Церкву, яка теж має власну педагогічну історію і налічує більше двох тисяч років. На глибоке переконання Іоанна Павла II, основні засади гуманної педагогіки, яка формує високу духовність особистості, закладені саме в християнській релігіі. Церква ніколи не стояла осторонь процесів виховання, неустанно нагадуючи, що “євангельська постать Ісуса є єдиним правдивим взірцем для людини" [11].

Понтифік зазначав, що було б помилковим вважати, що Церква наголошує лише на духовному елементі виховання: "Всі аспекти людського життя не $\epsilon$ чужими для церкви. Вона супроводжує людину від самого моменту їі народження i знаменується обрядом хрещення, яке символізує приєднання до церкви, до релігії.

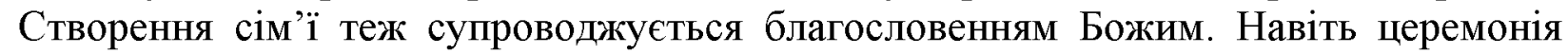
похорону нагадує про вічність i потребу примирення людини із своїм Творцем через сповідь і Святе Причастя" [19, с. 262].

Характерною особливістю педагогічних поглядів Іоанна Павла II, які сформувались під впливом персоналізму, є визнання двох пріоритетів, а саме: особовості та інтегральності. Щодо особовості, то він зазначав: “Виховання - це творчість у своїй суті найбільш особова, бо виховує завжди лише особу... все, що від природи дано людині, становить матеріал для вихователів, матеріал, який повинна сягнути їхня любов" [20, с. 54].

Будучи тонким психологом, Апостол християнської свідомості вважав, що надзвичайно важливе значення мають взаємовідносини між вихователем i вихованцем, які підпорядковуються так званій персоналістичній нормі, основна сутність якої виражається твердженням: "Особа $є$ таким буттям, що властивим до неї відношенням $є$ любов. Адже саме Бог заповідав людям вихідні принципи i норми поведінки та постулати життя, обгрунтовані любов'ю до ближнього" [20, c. 27-30].

Педагогіку Іоанна Павла II можна назвати виховною системою любові, бо саме любов він вважав наймогутнішим повчальним чинником, основною животворною силою, що дає змогу сформувати молоду людину. Іншими словами, персоналістична норма є виразом євангельської заповіді любові, перекладеної на мову філософської етики.

У вихованні, на думку Папи Римського, любов має бути розумною, керованою, реалізуватися в атмосфері справедливості. Інакше вона буде приречена на небезпеку та зловживання, а також принесе багато кривди і шкоди вихованцям. Вихованець повинен бачити в своєму наставникові благодійника, друга, що оберігає його, турбується про нього, намагається зробити його життя кращим. Тільки в цьому випадку вихователь з часом здобуде над своїми вихованцями мудру владу [5].

Другою характерною особливістю персоналізму $є$ інтегральність, тобто піклування про єдність тіла і душі. Для Іоанна Павла II людина є психосоматичною істотою [18, с. 75]. Саме тому інтегральний підхід до навчання і виховання дітей та 
молоді, вважав він, забезпечує фізичний, інтелектуальний та духовний розвиток особистості. Було б великою помилкою вважати, що персоналістична педагогіка визнає лише духовний елемент у процесі виховання. Людину Іоанн Павло II розглядав у поєднанні всіх аспектів, як тілесних, так і духовних. Тому його персоналістична педагогіка закликає формувати "серце - чеснотами, розум науками, тіло - вправами” [18, с. 14-15].

Понтифік акцентував на важливості національного виховання, оскільки розумів, що, успадковуючи віру, цінності - усе, що творить культуру та історію нації чи суспільства ... людина збагачується духовно як особистість [6, с. 14]. Як високодуховна людина, він особливо наголошував на праві кожного народу на свою мову і культуру, через які цей народ "виражає і зміцнюс те, що назвав би його первісною духовною "суверенністю“... Кожний народ має також право будувати своє життя згідно з власними традиціями... Кожний народ має право будувати своє майбутнє, забезпечуючи молодим людям виховання" [8, с. 29].

Понтифік відводив значну роль сім'ї, школі та церкві в особистісному утвердженні людини, адже тільки співпраця цих трьох інституцій допоможе досягти мети морального виховання - формування гармонійної, духовної, високоосвіченої особистості. Святий Отець вказував на необхідність підготовки молодих людей до створення сім'ї, до необхідності учити їх любові "Любов не дається до навчання, - писав він, - а з тим же ніщо більше так не надається до навчання, як любов! Це одна із сутей, на якій я зосередив своє священство, своє служіння на амвоні, у конфесіоналі, а також застосовуючи писане слово"[4].

Чільне місце у науковому доробку великого гуманіста і добротворця відведено родині й родинному вихованню: “Молодь і діти - це майбутнє світу, але це майбутнє неможливо збудувати без основи, яким є родина, школа, Церква i народ”[14, с. 85]. На думку Іоанна Павла II, сім'я $є$ першим і найбільш впливовим вихователем особистості, основним природнім виховним середовищем, в якому формується світ молодої людини та духовні цінності, які стануть основою іiї життя" [7].

Іоанн Павло II звертав увагу на необхідність підвищення ролі батька і матері у вихованні дітей. Квінтенсенцією його переконань можна вважати погляди на те, що саме батьки повинні знайомити дітей 3 релігійною культурою, виховувати шанобливе ставлення до неї. "Виховати серце дитини у цнотливості і благочесті священний обов'язок як батьків, так і матерів" [19, с. 128].

На ролі родини і мови наголошується в посланні Іоанна Павла II “До молоді всього світу”: “...Якшо родина є першим вихователем кожного..., через родину тим вихователем є рід, плем'я чи народ, з якими нас єднають культура, мова та історія. Найважливішою $є$ культурна спадщина, ядро якої формує мова. Батьки навчили вас тієї мови, яка здатна поєднати із суспільством, з іншими людьми. Ця єдність має ширші кордони, ніж сама родина ... Маю на увазі кордони ... нації чи народу" [6].

Однак Понтифік із гіркотою зазначав, що можливості сім’ї є обмеженими. Вона потребує допомоги та співпраці суспільства, виховним полем якого є школа та просвітницькі заклади для молоді. Місію школи Іоанн Павло II вбачав у “народженні людини до знань і мудрості”[19, с. 255]. Школа, на його думку, повинна не тільки навчати, але й виховувати, прищеплювати дітям та молоді принципи християнської моралі. 
Святий Отець наголошував на органічному взаємозв'язку між сім'єю, нацією i державою: “Сім'я, беручи участь у культурній спадщині, спричинює ту специфічну суверенність, яка випливає з власної культури та мови. Через свою культуру, свою мову не тільки народ, а й кожна сім'я здобуває свою духовну суверенність. Без цього важко було б пояснити багато подій в історії народів, особливо європейських; подій давніх і сьогоднішніх, подій піднесених і болісних, перемог і поразок, з яких видно, наскільки сім'я органічно поєднана 3 народом, а народ - із сім'єю" [8, с. 28].

Понтифік наголошував на важливій ролі праці у формуванні високоморальної людини. Зокрема в енцикліці Laborem exercens він писав: “Насамперед праця є власне даром і законом Божим, який становить сутність його як суб'єкта. Вона є природною властивістю й обов'язком, особливо дорослої людини, яка у професійній діяльності існує орієнтовно сорок років людського життя. Вона $\epsilon$ умовою формування людської екзистенції й утвердження справжньої людини" [11, с. 3].

Папа Іоанн Павло II часто спілкувався з молоддю, заохочував іiї до спільної діяльності, допомагав розширювати професійні та релігійні знання, наставляв цінувати людей і співпереживати їм, ставитись до них доброзичливо. "На Вас покладаємо надію, бо ви належите майбутньому, а майбутнє належить вам" говорив Понтифік у своєму посланні до молоді усього світу "Parati Semper" 3 нагоди Міжнародного року молоді [4, с. 1].

Він прагнув, щоб юнаки та дівчата жили згідно з Божими заповідями, ставали віруючими, принциповими, чесними, сумлінними і гідними довіри людьми. Адже “сумління завдяки моральним цінностям накладає свою печать на життя поколінь, на історію і на культуру суспільства, народів і всього людства" [4, c. 5]. Проповідуючи принципи гуманістичної педагогіки, духовний лідер закликав, щоб молоді люди жили за Божими законами і щоб своїм земним життям заслужили на "вічне блаженство".

Понтифік ініціював проведення Світових З’їздів Молоді, під час яких у простій та доступній формі намагався пояснити основи і правду християнської віри та моралі [13]. Під час таких зустрічей Папа Римський підкреслював, що прагнення юних до побудови кращого світу вимагає від них надання переваги духовним $\mathbf{i}$ Божим цінностям, закликав покладатися на Христа, пізнати i прийняти його [10]. Він був чудовим оратором, так як ще навчаючись у Ягеллонському університеті, захоплювався поезією та пробував себе у драматургічній творчості.

Великого мораліста хвилювала доля молодих людей, які потрапили у скрутні життсві обставини. Він вказував на необхідність рятувати їх від морального падіння, зберегти у них віру в Бога, добро, справедливість, навчити їх здобувати собі кусень хліба чесною працею. Кожен, з ким спілкувався Іоанн Павло II, міг відкрити йому своє серце, дістати від нього мудру пораду та розраду.

У системі педагогічних поглядів Іоанна Павла II вчені виокремлюють і педагогіку дозвілля. Пастир у своїх працях, листах, проповідях, повчаннях описує різні форми дозвілля, у тому числі спорт і туризм, які він особливо цінував, а також наголошує на прикладі вихователя щодо організації вільного часу. Іоанн Павло II цінував активні форми відпочинку на природі. В одній із свої праць він звертався до молоді: “Знайдіть час для цього! Не шкодуйте його! Прикладайте труд і зусилля на спілкування, єднання з природою. ... Цей труд $є$ творчим, водночас $є$ елементом 
здорового відпочинку, який необхідний так само, як навчання й робота" [ 2, с. 107$108]$.

Вже після смерті Понтифіка у 2005 р. була видана книжка “Пам'ять та ідентичність", написана у формі інтерв'ю, яка є “своєрідним духовним заповітом великого прочанина, який зі словом Божим простував до людей і ділився своєю мудрістю щодо культури, розуміння поняття Європи, сучасних моральних i соціальних питань, причин падінь і злетів людського духу" [11, с. 13].

Висновки. Аналіз філософсько-педагогічної спадщини Папи Іоанна Павла II та його подвижницької діяльності уможливлює висновок про те, що основою морального становлення зростаючого покоління він вважав християнське виховання, яке охоплює усі сфери людського життя: особисту, сімейну, громадянську, національну, суспільну тощо. Християнські канони $\epsilon$ базою для поширення зпоміж дітей та молоді загальноприйнятих духовних цінностей, таких, як доброта, порядність, любов, вірність, чесність, гідність, мудрість, справедливість та ін. Сьогодні ім'ям Іоанна Павла II названі вулиці у Хмельницькому, ІваноФранківську, Вінниці, Житомирі та інших містах України. Україна стає частиною Європи, про яку мріяв Іоанн Павло II. Його активна участь у поширенні гуманістичних ідеалів забезпечила йому гідне місце як в церковній, так і в світській iсторії. Папа Римський Іоанн Павло II сам був прикладом такого способу життя, сам жив за тими християнськими принципами, які проповідував.

Література

1. Вайгель Джордж. Свідок надії. Життєпис Папи Івана Павла II. Львів: вид-во Українського Католицького університету, 2011.

2. Дашиковська Я. Значення вільного часу для людини в роздумах і педагогічній діяльності Іоанна Павла II. Естетика і етика педагогічної дії. 2013. Вип.5. С.99-112.

3. Захара I. Дешо про філософські погляди Івана Павла II. Богослов 'я. 2000. Т.64. С.159-166.

4. Іван-Павло II Апостольське послання до молоді всього світу "Parati Semper". URL: milites.christi.imperatoris@gmail.com (дата звернення 1 березня 2019 р.)

5. Іван Павло II. Енцикліка Fides et Radio Святішого Отця Івана Павла II до єпископів Католицької Церкви про співвідношення віри й розуму. Київ: Кайрос, 2000. 152 с.

6. Іван Павло II. Послання Папи Івана Павла II. К.: Літопис, 2001. 27 c. URL: < www.litopys.lviv.ua/.../filosofija_1.html > (дата звернення 1 березня 2019 p.).

7. Іван Павло II. Лист до сімей з нагоди року сім'ї. Київ. 1995. 96 с.

8. Ничкало Н. Філософія педагогіки серця Яна Павла II• Рідна икола. №4-5 (квітень-травень) 2012. c.24-31.

9. Папа Іван-Павло II Апостольське послання до молоді всього світу "Parati Semper”. URL: milites.christi.imperatoris@gmail.com. (дата звернення 2березня 2019 p.).

10. Сахній М. Формування морально-етичних рис молодої людини крізь призму філософськопедагогічних поглядів Івана Павла ІІ. Гірська школа Украйнських Карпат. № 10 (2013). C. 106-109.

11. Семеног О. Цінності учительської праці в рефлексіях Івана Павла II. Професійна освіта: педагогіка $і$ психологія: Польсько-український щорічник / За. ред.Т.Левовицького, І.Вільш, I.Зязюна, Н.Ничкало. Ченстохова-Київ, 2013. C.2-8. URL: dlibra.bg.ajd.czest.pl:8080/ Content/1404 (дата звернення 3 березня 2019 р.).

12. Федорів О., Михайлів О. Іоанн Павло II - Папа Миру. Тернопіль: Підручники і Посібники, $2001.95 \mathrm{c}$

13. Хайлик Й. Приятель молоді / Йосиф Хайлик. URL: osbm - krystynopil.com.ua/stati/ pryjatelmolodi.htm. (дата звернення 3 березня 2019 p.).

14. Chrobak S. Koncepcja wychowania personalistycznego w nauczaniu Karola Wojtyly Jana- Pawla 11. Warszawa : Wyd Salezjanskie, 1999. $160 \mathrm{~s}$.

15. Grondelski J. M. Sourses for the Studi of Karol Wojtylas Thought // At the Center of the Human Drama. The Philosophical Anthropology of Karol Wojtyla / Pope John Paul 11 / K.L. Schmitz (ed.). Washington : The Catholic University of America Press ,1993. P. 147-163. 
16. Guietti P., Murphy F. Quindici anni di staid sul pensiero di Karol Wojtyla // $\Pi$ pensiero dell uomo che divenne Giovanni Paollo / R Buttiglione (a cura). Milano : Mondadori, 1998. P. 387-420.

17. Kazmierczak P. Personalistyczna koncepcja w nauczaniu Jana Pawla. Krakow: Wyd. WAM, 2003. $183 \mathrm{~s}$.

18. Makowka A. Pedagogika ewangeliczna Jana Pawla П.-Kalwaria Zebrzydowska: Calvarianum, 2003. $239 \mathrm{~s}$.

19. Rynio A Integralne wychowanie w mysli Jana Pawla 11. Lublin : Wyd. KUL, 2004. $477 \mathrm{~s}$.

20. Wojtyla K Milosc I odpowiedzialnosc. Studium etyczn. Lublin: Tow. Nauk. KUL, 1893. 255 s.

21. Wojtila K. Osoba I czyn. Krakow: Polskie Towarzystwo Teologiczne, 1969. $325 \mathrm{~s}$.

22. Wronska K Osoba I wychowanie: wokol personalistycznej filozofii wychowania Karola Wojtyly Jana Pawla П.Krakow: Wyd. Uniwersytetu Jagiellonskiego, 2000. $130 \mathrm{~s}$.

\section{References}

1. Vaihel Dzhordzh. Svidok nadii. Zhyttiepys Papy Ivana Pavla II / Dzhordzh Vaihel. Lviv: vyd-vo Ukrainskoho Katolytskoho universytetu, 2011.

2. Dashykovska Yadviha. Znachennia vilnoho chasu dlia liudyny v rozdumakh i pedahohichnii diialnosti Ioanna Pavla II. Estetyka i etyka pedahohichnoi dii. 2013. Vyp.5. S.99-112.

3. Zakhara I. Deshcho pro filosofski pohliady Ivana Pavla II. Bohoslovia. 2000. T.64. S.159-166.

4. Ivan Pavlo II. Entsyklika Fides et Radio Sviatishoho Ottsia Ivana Pavla II do yepyskopiv Katolytskoi Tserkvy pro spivvidnoshennia viry y rozumu. Kyiv: Kairos, 2000. 152 s.

5. Ivan Pavlo II. Poslannia Papy Ivana Pavla II. - K.: Litopys, 2001. - 27 s. KhY: $<$ www.litopys.lviv.ua/.../filosofija_1.html $>$.

6. Ivan Pavlo II. Lyst do simei z nahody roku simi. Kyiv. 1995. $96 \mathrm{~s}$.

7. Nychkalo N. Filosofiia pedahohiky sertsia Yana Pavla II. Ridna shkola. №4-5 (kviten-traven) 2012. S.24-31.

8. Papa Ivan-Pavlo II Apostolske poslannia do molodi vsoho svitu "Parati Semper". KhY: milites.christi.imperatoris@gmail.com.

9. Sakhnii M. Formuvannia moralno-etychnykh rys molodoi liudyny kriz pryzmu filosofskopedahohichnykh pohliadiv Ivana Pavla II. Hirska shkola Ukrainskykh Karpat. № 10 (2013). S.106110.

10. Semenoh O. Tsinnosti uchytelskoi pratsi v refleksiiakh Ivana Pavla II Profesiina osvita: pedahohika i psykholohiia: Polsko-ukrainskyi shchorichnyk / Za. red. T.Levovytskoho, I.Vilsh, I.Ziaziuna, N.Nychkalo. Chenstokhova-Kyiv, 2013. Vyp. KhY: dlibra.bg.ajd.czest.pl:8080/ Content/1404

11. Slovnyk inshomovnykh sliv / Za red. O.S.Melnychuka. Kyiv. 1974. $775 \mathrm{~s}$.

12. Fedoriv O., Mykhailiv O. Ioann Pavlo II Papa Myru. Ternopil: Pidruchnyky i Posibnyky, 2001. 95 s.

13. Khailyk Y. Pryiatel molodi. KhY: osbm - krystynopil.com.ua/stati/ pryjatelmolodi.htm

14. Shrobak S. Koncepcja wychowania personalistycznego w nauczaniu Karola Wojtyly Jana- Pawla 11. Warszawa : Wyd Salezjanskie, 1999.160 s.

15. Grondelski J. M. Sourses for the Studi of Karol Wojtylas Thought // At the Center of the Human Drama. The Philosophical Anthropology of Karol Wojtyla / Pope John Paul 11 / K.L. Schmitz (ed.). Washington: The Catholic University of America Press , 1993. P. 147-163.

16. Guietti P., Murphy F. Quindici anni di staid sul pensiero di Karol Wojtyla // P pensiero dell uomo che divenne Giovanni Paollo / R Buttiglione (a cura). Milano : Mondadori, 1998. P. 387-420.

17. Kazmierczak P. Personalistyczna koncepcja w nauczaniu Jana Pawla. Krakow: Wyd. WAM, 2003. $183 \mathrm{~s}$.

18. Makowka A. Pedagogika ewangeliczna Jana Pawla P.-Kalwaria Zebrzydowska: Calvarianum, 2003. $239 \mathrm{~s}$.

19. Rynio A Integralne wychowanie w mysli Jana Pawla 11. Lublin : Wyd. KUL, 2004. $477 \mathrm{~s}$.

20. Wojtyla K Milose I odpowiedzialnosc. Studium etyczn. Lublin: Tow. Nauk. KUL, 1893. 255 s.

21. Wojtila K. Osoba I czyn. Krakow: Polskie Towarzystwo Teologiczne, 1969. $325 \mathrm{~s}$.

22. Wronska K Osoba I wychowanie: wokol personalistycznej filozofii wychowania Karola Wojtyly Jana Pawla P.Krakow: Wyd. Uniwersytetu Jagiellonskiego, 2000. $130 \mathrm{~s}$.

Одержано статтю: 23.01 .2019

Прийнято до друку: 26.02.2019 